\title{
EVALUATION OF GRAPHICAL AND MULTIVARIATE STATISTICAL METHODS FOR CLASSIFICATION AND EVALUATION OF GROUNDWATER IN ALATHUR BLOCK, PERAMBALUR DISTRICT, INDIA
}

\author{
AHAMED, A. J..$^{*}$ - LOGANATHAN, K. ${ }^{1}$ - ANANTHAKRISHNAN, S. ${ }^{2}-$ AHMED, J. K. C. ${ }^{3}$ \\ ASHRAF, M. A. ${ }^{45^{*}}$ \\ ${ }^{I} P G$ and Research Department of Chemistry, Jamal Mohamed College (Autonomous), affiliated \\ to Bharathidasan University, Tiruchirappalli - 620 020, Tamilnadu, India \\ ${ }^{2}$ Department of Chemistry, Rover Engineering College, Perambalur - 621 212, Tamilnadu, \\ India \\ ${ }^{3}$ Institute of Oceanography and Maritime Studies (INOCEM), Kulliyyah of Science \\ International Islamic University Malaysia 25200 Kuantan, Pahang, Malaysia \\ ${ }^{4}$ Department of Environmental Sciences and Engineering, School of Environmental Studies, \\ China University Of Geosciences, 430074 Wuhan, P.R. China \\ ${ }^{5}$ International Water, Air \& Soil Conservation Society, Kuala Lumpur, Malaysia \\ *Corresponding author \\ e-mail:agjafar@yahoo.co.in \\ (Received 22 $2^{\text {nd }}$ Jul 2016; accepted 20 ${ }^{\text {th }}$ Dec 2016)
}

\begin{abstract}
This paper assesses the quality of water using different graphical and statistical methods like Durov, Schoeller, Piper - Tri linear diagram, Box and Whisker plot for three seasons in the study area Alathur block, Perambalur District. The graphical representation provides limitations compared with the multivariate method for large data sets. A total of 10 groundwater samples were collected from hand dug wells in this area and they were analyzed for various physical and chemical parameters. The sequence of the dominance of the major ions are in the following order $\mathrm{Na}^{+}>\mathrm{Ca}^{2+}>\mathrm{Mg}^{2+}>\mathrm{K}^{+}$and $\mathrm{Cl}^{-}>\mathrm{SO}_{4}{ }^{2-}>$ $\mathrm{HCO}_{3}^{-}>\mathrm{NO}_{3}{ }^{-}$. The dominating hydrochemicals of facies of groundwater are $\mathrm{Ca}-\mathrm{Cl}$ and mixed $\mathrm{Ca}-\mathrm{Mg}-\mathrm{Cl}$ and alkaline earth metals $\left(\mathrm{Ca}^{2+}, \mathrm{Mg}^{2+}\right)$ and strong acids $\left(\mathrm{SO}_{4}{ }^{2-}, \mathrm{Cl}^{-}\right)$that dominate over alkalis $\left(\mathrm{Na}^{+}, \mathrm{K}^{+}\right)$ and weak acids like $\mathrm{HCO}_{3}{ }^{-}, \mathrm{CO}_{3}{ }^{-}$. Based on the analytical result, groundwater in the study area is generally hard to very hard, slightly alkaline to brackish in nature. This indicates that leaching of salts, rock weathering and evaporation are among the most dominant processes in controlling water quality. For industrial purposes, the quality of water was assessed by using the Langeliner saturation index (LSI) and Ryznar saturation index (RSI). Seasonal variations in different parameters were also determined.
\end{abstract}

Keywords: graphical representation, hydrochemical analysis, Durov, Schoeller plot, Piper diagram

\section{Introduction}

The need to maintain environmental quality through sustainable use of resources has been emphasized by environmentalists. The overall human activities are designed and implemented for the economic growth of a country and societal needs, would directly or indirectly have a bearing on the environment especially to water (Joseph and Nagendran, 2004). Several water sources are affected due to the rapid growth of population industrialization and urbanization. Concerns and consequence related to the environment are inextricable and are lined to economic issues such as poverty which drive people to indulge in destructive activities like cutting of trees and over exploitation of water 
resources. These activities lead to changes in the hydrological cycle, change in climatic conditions, rainfall patterns, etc. The study is undertaken to analyze the above said parameters. The quality of groundwater has been studied in several basins by many researchers (Ramesh and Jagadeewari, 2012; Cobbian et al., 2012). The knowledge of hydrochemistry is essential to determine the origin of chemical composition of groundwater (Zaporozec, 1972). The hydrogeochemical evaluation study is becoming very important to determine the processes involved in the chemical evolution of groundwater (Andrade and Stigter, 2011; Singh et al., 2012a). People also mostly depend upon the groundwater as the water resource for all the activities like drinking, agriculture and domestic use. The study area is predominantly agricultural zone with dense agriculture activities going on throughout the year. Hence, in the present study baseline attempt has been made to study the subsurface water quality in various seasons.

\section{Materials and Methods}

\section{Study Area}

Perambalur district of India mainly depends upon agriculture as a main source of gross income of the people. The major crops of the district are small onion. Onion is cultivated in more than 22 thousand hectares. Other crops are paddy, sugar, maize, millet, etc. The district receives rainfall mostly during the northeast monsoon season as $908 \mathrm{~mm}$ which is lesser when compared to other districts. The district is predominantly covered by red loam and black soil. Using the software Arc GIS 9.3.1, we got a picture presented in Figure 1 which shows different types of rocks present in the Alathur zone. It consists of coarse sandstone with day, argillaceous sandstone, sandstone \& shales, charnockites, Shales with bands of limestone, Sandstone with calcareous gritstone, sandstone, pebbly sandstone \& clay, gypseterous clay, sand and silt. Alathur is a major block in Perambalur district, which lies from $11^{\circ} 10^{\prime} \mathrm{N}, 78^{\circ} 41^{\prime} \mathrm{E}$ to $11^{\circ} 10^{\prime} \mathrm{N}, 7^{\circ} 05^{\prime} \mathrm{E}$ (Figure 1).

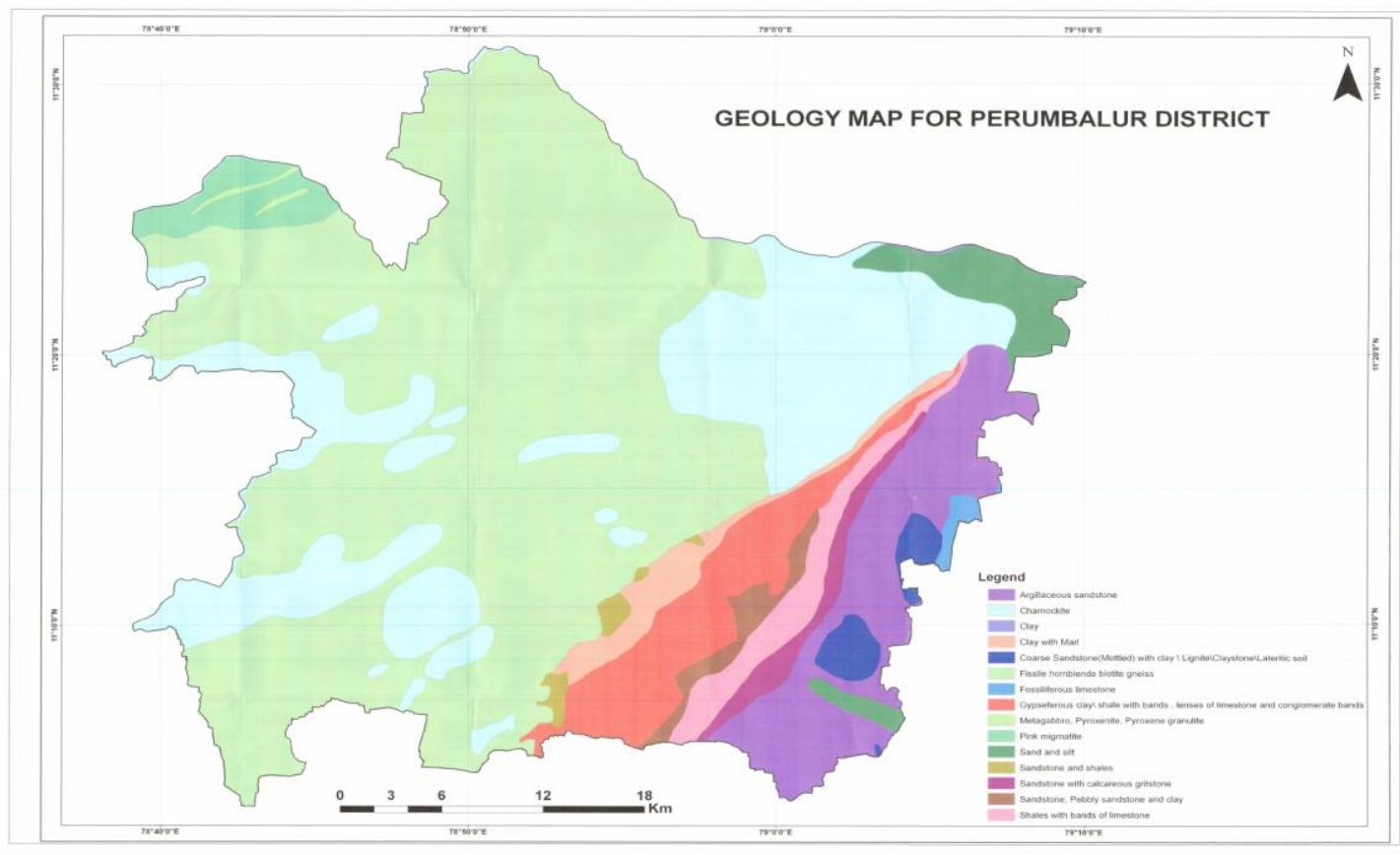

Figure 1. Map of the study area 


\section{Methodology}

From bore well, ten groundwater samples were collected in different seasons through the year 2012-2013: November 2012 (Monsoon), February 2013 (Post-monsoon), and May 2013 (summer). The samples were analyzed using standard procedures (APHA, 2005). Major cation such as $\mathrm{Ca}$ and $\mathrm{Mg}$ were analyzed titrimetrically, $\mathrm{Na}$ and $\mathrm{K}$ by flame photometer, major anions $\mathrm{Cl}$ and $\mathrm{HCO}_{3}$ titrimetrically and chloride was determined by $\mathrm{AgNO}_{3}$ titration (Vogel 1968) method. $\mathrm{SO}_{4}$ and $\mathrm{PO}_{4}$ were analyzed using a spectrophotometer. $\mathrm{EC}$ and $\mathrm{pH}$ were determined in the field itself using multiparameter water quality probe (Elico PE 138).

\section{Result and Discussion}

It is very essential to understand the quality of groundwater for different purposes. Nowadays, due to man-made activities, like frequent climatic change and rainfall pattern year by year, precipitation quantity is reduced due to above mentioned reasons. The physicochemical parameters of all water samples for all the three seasons were analyzed and presented in the Table 1 .

Principle of graphical and numerical presentation of chemically analyzed water is based on the relationships of group of ions forming a chemical type of water. A single graph will not give all of the information such as concentration of ions, comparison of the proportions of the ions, classification of water type and identification of mixed waters of different composition identification of any of the chemical process that may take place in groundwater circulation or the relationship of chemical composition to rock type.

\section{General Parameters}

The physicochemical characteristics of groundwater of to ten stations are presented in Table 1 for all three seasons. The $\mathrm{pH}$ values vary from 7.04 to 8.38 indicating the alkaline nature of groundwater samples. All $\mathrm{pH}$ values are within the permissible limit (6.5 - 8.5) of the Bureau of Indian Standards (BIS, 1998). The Electrical conductivity (EC) varies from 808 to $5207 \mu \mathrm{S} / \mathrm{cm}$. The station S7 exceeds the BIS permissible limit of $3000 \mu \mathrm{S} / \mathrm{cm}$ in two seasons. In natural waters the dissolved solids are mainly concentration of carbonates, bicarbonates, chlorides, sulfates, phosphates and nitrates of calcium, magnesium, sodium and potassium with traces of iron, manganese and other minerals. Organic matter and various dissolved gases are also present in small amounts (Jain, 2010) The TDS value lies between 565 to $3645 \mathrm{mg} / \mathrm{L}$. The station S7 exceeds the permissible limit of $2000 \mathrm{mg} / \mathrm{L}$ (BIS, 1998). Water having high TDS values is used for drinking purposes and it induces unfavorable physiological reaction, in the transient consumer and gastrointestinal irritation (Shankar et al., 2008). The total hardness in our study area varies from 219 to $697 \mathrm{mg} / \mathrm{L}$. The sample S7, in two seasons the TH exceeds BIS permissible limit. The total hardness is due to the presence of cation in the water as primary causes for excess of hardness do not give lather to soap solutions. 
Table 1. Physicochemical characteristics of groundwater samples

\begin{tabular}{|c|c|c|c|c|c|c|c|c|c|c|c|c|c|c|}
\hline Station & EC & TDS & $\mathbf{p H}$ & TH & $\mathbf{C a}$ & $\mathbf{M g}$ & $\mathbf{N a}$ & $\mathbf{K}$ & $\mathrm{NO}_{3}$ & $\mathbf{C l}$ & $\mathbf{F}$ & $\mathrm{SO}_{4}$ & $\mathrm{PO}_{4}$ & $\mathrm{HCO}_{3}$ \\
\hline \multicolumn{15}{|c|}{ November (Monsoon) } \\
\hline S1 & 1732 & 1212 & 7.32 & 287 & 57 & 35 & 136 & 42 & 13 & 202 & 0.6 & 157 & 0.08 & 323 \\
\hline $\mathrm{S} 2$ & 1458 & 1021 & 7.16 & 382 & 77 & 45 & 185 & 24 & 16 & 182 & 0.2 & 162 & 0.01 & 251 \\
\hline $\mathrm{S} 3$ & 1292 & 904 & 7.21 & 314 & 64 & 37 & 125 & 35 & 11 & 129 & 0.4 & 43 & 0.07 & 485 \\
\hline S4 & 1399 & 980 & 7.57 & 326 & 66 & 39 & 101 & 46 & 13 & 133 & 0.2 & 124 & 0.34 & 343 \\
\hline S5 & 1814 & 1270 & 7.12 & 306 & 62 & 36 & 175 & 55 & 14 & 273 & 1 & 82 & 0.03 & 416 \\
\hline S6 & 808 & 565 & 7.8 & 271 & 56 & 32 & 66 & 22 & 0 & 40 & 0.6 & 32 & 0 & 323 \\
\hline S7 & 5190 & 3633 & 7.47 & 677 & 119 & 91 & 675 & 175 & 39 & 899 & 0.6 & 934 & 0.06 & 545 \\
\hline S8 & 1767 & 1237 & 7.23 & 219 & 43 & 27 & 212 & 67 & 16 & 172 & 0.4 & 135 & 0.07 & 444 \\
\hline S9 & 1968 & 1378 & 7.52 & 338 & 68 & 40 & 254 & 61 & 26 & 253 & 0.8 & 167 & 0.28 & 384 \\
\hline S10 & 2387 & 1671 & 7.04 & 470 & 96 & 55 & 312 & 54 & 21 & 434 & 0.4 & 193 & 0.31 & 416 \\
\hline \multicolumn{15}{|c|}{ February (Post monsoon) } \\
\hline S1 & 1834 & 1283 & 7.13 & 291 & 56 & 36 & 140 & 51 & 16 & 230 & 0 & 189 & 0 & 343 \\
\hline $\mathrm{S} 2$ & 1458 & 1021 & 7.08 & 505 & 78 & 74 & 191 & 31 & 26 & 158 & 0 & 179 & 0.1 & 255 \\
\hline S3 & 1516 & 1061 & 7.6 & 489 & 76 & 72 & 126 & 39 & 3 & 186 & 0 & 92 & 0 & 440 \\
\hline S4 & 1215 & 851 & 7.15 & 218 & 53 & 21 & 124 & 52 & 17 & 113 & 0 & 105 & 0.1 & 279 \\
\hline S5 & 1873 & 1311 & 7.19 & 444 & 80 & 59 & 182 & 58 & 17 & 295 & 1 & 81 & 0 & 408 \\
\hline S6 & 815 & 571 & 8.16 & 380 & 76 & 46 & 60 & 19 & 1 & 44 & 0 & 35 & 0 & 327 \\
\hline S7 & 5207 & 3645 & 7.67 & 697 & 119 & 96 & 698 & 179 & 47 & 899 & 1 & 512 & 0 & 537 \\
\hline S8 & 1617 & 1132 & 8.07 & 291 & 43 & 44 & 235 & 61 & 23 & 149 & 0 & 58 & 0.3 & 440 \\
\hline S9 & 1985 & 1389 & 7.53 & 202 & 41 & 24 & 268 & 66 & 26 & 311 & 1 & 69 & 0 & 364 \\
\hline $\mathrm{S} 10$ & 2286 & 1600 & 7.04 & 485 & 97 & 58 & 326 & 50 & 22 & 434 & 0 & 175 & 0.1 & 444 \\
\hline \multicolumn{15}{|c|}{ May (Summer) } \\
\hline S1 & 1717 & 1202 & 7.44 & 384 & 92 & 37 & 163 & 67 & 15 & 250 & 1 & 118 & 0.15 & 291 \\
\hline S2 & 1557 & 1090 & 7.22 & 590 & 178 & 35 & 98 & 21 & 14 & 182 & 0.8 & 238 & 0.05 & 198 \\
\hline S3 & 1562 & 1094 & 7.45 & 598 & 99 & 86 & 89 & 37 & 14 & 250 & 0.8 & 29 & 0.16 & 404 \\
\hline S4 & 1445 & 1012 & 7.72 & 372 & 91 & 35 & 124 & 47 & 12 & 214 & 0.4 & 144 & 0.02 & 206 \\
\hline S5 & 1792 & 1254 & 7.51 & 513 & 92 & 68 & 154 & 60 & 18 & 283 & 1 & 102 & 0.17 & 315 \\
\hline S6 & 1948 & 1363 & 7.96 & 566 & 124 & 61 & 187 & 66 & 22 & 218 & 1.2 & 355 & 0.03 & 327 \\
\hline S7 & - & - & - & - & - & - & - & - & - & - & - & - & - & - \\
\hline S8 & 1525 & 1068 & 7.78 & 356 & 54 & 53 & 147 & 54 & 17 & 194 & 0.6 & 98 & 0.15 & 307 \\
\hline S9 & 1996 & 1397 & 8.38 & 392 & 68 & 53 & 214 & 61 & 25 & 271 & 0.8 & 124 & 0.53 & 376 \\
\hline S10 & 1716 & 1202 & 7.96 & 354 & 96 & 28 & 187 & 45 & 15 & 293 & 0.4 & 105 & 0.36 & 323 \\
\hline
\end{tabular}

All the values are in $\mathrm{mg} / \mathrm{L}$ except $\mathrm{pH}$ and $\mathrm{EC}$. EC is expressed in $\mu \mathrm{S} / \mathrm{cm}$

\section{Cation Chemistry}

The concentrations of various cations analyzed in groundwater for three seasons are presented in Table 1. The major cations present in most of the ground waters have highest concentrations (all $>1 \mathrm{mg} / \mathrm{L}$ ). They are calcium, magnesium, sodium and 
potassium (Younger, 2007). Calcium and magnesium concentrations vary from 41 to $124 \mathrm{mg} / \mathrm{Land} 24$ to $89 \mathrm{mg} / \mathrm{L}$ respectively. In groundwater the calcium content, generally exceeds the magnesium content in accordance with their relative abundance in rocks. All the samples in three seasons are within the BIS permissible limit of $200 \mathrm{mg} / \mathrm{L}$. Sodium and potassium concentrations vary from 60 to $698 \mathrm{mg} / \mathrm{L}$ and 19 to $179 \mathrm{mg} / \mathrm{L}$, respectively except one sample in two seasons which exceeds the BIS permissible limit $200 \mathrm{mg} / \mathrm{L}$. Potassium in all the samples in three seasons exceeds the BIS permissible value of $10 \mathrm{mg} / \mathrm{L}$. High $\mathrm{Ca}^{2+}, \mathrm{Mg}^{2+}, \mathrm{Na}^{+}$and $\mathrm{K}^{+}$concentrations are mainly due to their mineralogical origin in the soil weathering of feldspar and montmorillonite. It generates the water soluble $\mathrm{Na}^{+}$and $\mathrm{K}^{+}$ions. In addition, cation exchange processes and agricultural, industrial activities also contribute for high $\mathrm{Na}^{+}$and $\mathrm{K}^{+}$concentration in the study area (Naidu et al., 1985; Singh et al., 1997; Singh et al., 2006).

\section{Anion Chemistry}

The concentrations of various anions analyzed in the groundwater samples are presented in Table 1 for three seasons. The major ions having highest concentrations (all $>1 \mathrm{mg} / \mathrm{L}$ ) in groundwater are bicarbonates, sulphates and chlorides (Naidu et al., 1985). In the present study, groundwater contains predominant anion is chloride, which varies from 40 to $899 \mathrm{mg} / \mathrm{L}$ and the desirable limit recommended by WHO is $250 \mathrm{mg} / \mathrm{L}$. Above $30 \%$ of samples exceeds the desirable limits in all three seasons and however, no adverse health effects on human being have been reported by the use of water having high chloride contents (Jain, 2010). The sulphate concentration in groundwater is due to the presence of soluble salts like calcium, magnesium and sodium. Rainfall infiltration and groundwater recharge gives significant change in sulphate concentration (Jain, 2010). The sulphate concentration in our study area varies from 29 to $934 \mathrm{mg} / \mathrm{L}$. The station S7 exceeds the BIS permissible limit of $400 \mathrm{mg} / \mathrm{L}$ in two seasons. Sulphate present alone may not give any adverse health effects while presence of sulphate in excess of greater than $400 \mathrm{mg} / \mathrm{L}$ with sodium or magnesium may lead to gastrointestinal irritations (Shankar et al., 2008). The permissible limit for bicarbonate is $250 \mathrm{mg} / \mathrm{L}$, in all three seasons, bicarbonate ranges from 206 to $545 \mathrm{mg} / \mathrm{L}$. India is an agricultural based country. Many parts of India are reported to have high nitrate concentration in the groundwater, due to over usage of nitrogen fertilizers which changes the natural drainage patterns.

Nitrate concentration $>45 \mathrm{mg} / \mathrm{L}$ in drinking water has adverse health effects on human's results in methaemoglobinaemia which generally affects the infants (Jain, 2010) and gastriccarcinona (Tank and Chandel, 2010). The nitrate concentration ranges from 0 to $47 \mathrm{mg} / \mathrm{L}$. The phosphate concentration is very low in the study area in all the three seasons. The fluoride concentrations in all three seasons are well within the permissible limit of $1.5 \mathrm{mg} / \mathrm{L}$. In India, due to high fluoride concentration geoenvironmental problems are present and generally fluoride concentration is due to natural process (Singh et al., 2012b).

\section{Correlation analysis}

Person Correlation analysis is a useful method in hydrogeochemical studies since the produced correlation matrix can indicate the associations between individual parameters demonstrating the overall coherence of the data set and revealing the links between individual parameters and various controlling factors (Wang and Jiao, 2012). In the 
current study, the statistical software package SPSS 17.0 is used to calculate Pearson correlation coefficient. The result obtained for all the three seasons are presented in Table 2. From the data's, all major cations and anions with the exception of $\mathrm{PO}_{4}$ were positively correlated with TDS. Theses correlation coefficient are large 0.9 for all three season for $\mathrm{Na}$ and $>0.5$ for $\mathrm{Ca}, \mathrm{Mg}$, and $\mathrm{Cl}$ and all are significant at the 0.01 level. It can be judged from the analysis that during groundwater flow, the following reaction has likely taken place:

$$
\begin{aligned}
\mathrm{NaCl} & =\mathrm{Na}^{+}+\mathrm{Cl}^{-} \\
\mathrm{Na}_{2} \mathrm{SO}_{4} & =2 \mathrm{Na}^{+}+\mathrm{SO}_{4}{ }^{2-} \\
\mathrm{CaSO}_{4} & =\mathrm{Ca}^{2}+\mathrm{SO}_{4}{ }^{2-} \\
\mathrm{MgSO}_{4} & =\mathrm{Mg}^{2+}+\mathrm{SO}_{4}{ }^{2-}
\end{aligned}
$$

\begin{tabular}{|c|c|c|c|c|c|c|c|c|c|c|c|c|c|}
\hline Parameters & EC & TDS & PH & TH & $\mathrm{Ca}$ & Mg & $\mathbf{N a}$ & $\mathrm{NO}_{3}$ & Cl & $\mathbf{F}$ & $\mathrm{SO}_{4}$ & $\mathbf{P O}_{4}$ & $\mathrm{HCO}_{3}$ \\
\hline \multicolumn{14}{|c|}{ (a)November } \\
\hline $\mathrm{EC}$ & 1 & & & & & & & & & & & & \\
\hline TDS & 1.00 & 1 & & & & & & & & & & & \\
\hline PH & -0.05 & -0.05 & 1 & & & & & & & & & & \\
\hline TH & 0.89 & 0.90 & -0.05 & 1 & & & & & & & & & \\
\hline $\mathrm{Ca}$ & 0.83 & 0.83 & -0.10 & 0.99 & 1 & & & & & & & & \\
\hline Mg & 0.93 & 0.93 & 0.00 & 0.99 & 0.96 & 1 & & & & & & & \\
\hline $\mathrm{Na}$ & 0.98 & 0.98 & -0.08 & 0.90 & 0.85 & 0.93 & 1 & & & & & & \\
\hline $\mathrm{NO}_{3}$ & 0.91 & 0.91 & -0.17 & 0.81 & 0.77 & 0.82 & 0.92 & 1 & & & & & \\
\hline $\mathrm{Cl}$ & 0.99 & 0.99 & -0.12 & 0.93 & 0.88 & 0.95 & 0.98 & 0.89 & 1 & & & & \\
\hline $\mathrm{F}$ & 0.17 & 0.17 & 0.07 & -0.02 & -0.06 & 0.00 & 0.14 & 0.13 & 0.19 & 1 & & & \\
\hline $\mathrm{SO}_{4}$ & 0.97 & 0.97 & 0.10 & 0.89 & 0.82 & 0.94 & 0.95 & 0.85 & 0.94 & 0.07 & 1 & & \\
\hline $\mathrm{PO}_{4}$ & 0.02 & 0.02 & 0.04 & 0.11 & 0.18 & 0.05 & 0.02 & 0.24 & 0.04 & -0.21 & -0.06 & 1 & \\
\hline $\begin{array}{l}\mathrm{HCO}_{3} \\
\text { (b)February }\end{array}$ & 0.66 & 0.66 & -0.15 & 0.47 & 0.41 & 0.51 & 0.65 & 0.56 & 0.64 & 0.26 & 0.56 & 0.00 & 1 \\
\hline EC & 1 & & & & & & & & & & & & \\
\hline TDS & 1.00 & 1 & & & & & & & & & & & \\
\hline PH & -0.01 & -0.01 & 1 & & & & & & & & & & \\
\hline $\mathrm{TH}$ & 0.64 & 0.64 & -0.03 & 1 & & & & & & & & & \\
\hline $\mathrm{Ca}$ & 0.66 & 0.66 & -0.11 & 0.94 & 1 & & & & & & & & \\
\hline $\mathrm{Mg}$ & 0.62 & 0.62 & 0.03 & 0.98 & 0.85 & 1 & & & & & & & \\
\hline $\mathrm{Na}$ & 0.97 & 0.97 & 0.03 & 0.61 & 0.63 & 0.59 & 1 & & & & & & \\
\hline $\mathrm{NO}_{3}$ & 0.83 & 0.83 & -0.16 & 0.37 & 0.36 & 0.38 & 0.89 & 1 & & & & & \\
\hline $\mathrm{Cl}$ & 0.99 & 0.99 & -0.08 & 0.65 & 0.71 & 0.60 & 0.96 & 0.81 & 1 & & & & \\
\hline $\mathrm{F}$ & 0.60 & 0.60 & 0.00 & 0.20 & 0.23 & 0.20 & 0.57 & 0.55 & 0.62 & 1 & & & \\
\hline $\mathrm{SO}_{4}$ & 0.93 & 0.93 & -0.14 & 0.70 & 0.72 & 0.67 & 0.88 & 0.78 & 0.89 & 0.355 & 1 & & \\
\hline $\mathrm{PO}_{4}$ & -0.20 & -0.20 & 0.19 & -0.24 & -0.35 & -0.16 & -0.04 & 0.14 & -0.25 & -0.429 & -0.219 & 1 & \\
\hline $\begin{array}{l}\mathrm{HCO}_{3} \\
\text { (c)May }\end{array}$ & 0.73 & 0.73 & 0.30 & 0.54 & 0.51 & 0.54 & 0.71 & 0.41 & 0.74 & 0.421 & 0.507 & -.006 & 1 \\
\hline $\mathrm{EC}$ & 1 & & & & & & & & & & & & \\
\hline TDS & 1.00 & 1 & & & & & & & & & & & \\
\hline PH & 0.97 & 0.97 & 1 & & & & & & & & & & \\
\hline TH & 0.79 & 0.79 & 0.78 & 1 & & & & & & & & & \\
\hline $\mathrm{Ca}$ & 0.63 & 0.63 & 0.63 & 0.85 & 1 & & & & & & & & \\
\hline $\mathrm{Mg}$ & 0.68 & 0.68 & 0.66 & 0.79 & 0.36 & 1 & & & & & & & \\
\hline $\mathrm{Na}$ & 0.90 & 0.90 & 0.84 & 0.45 & 0.33 & 0.41 & 1 & & & & & & \\
\hline $\mathrm{NO}_{3}$ & 0.93 & 0.93 & 0.86 & 0.66 & 0.44 & 0.66 & 0.91 & 1 & & & & & \\
\hline $\mathrm{Cl}$ & 0.92 & 0.92 & 0.91 & 0.69 & 0.49 & 0.65 & 0.83 & 0.79 & 1 & & & & \\
\hline $\mathrm{F}$ & 0.79 & 0.79 & 0.67 & 0.81 & 0.61 & 0.72 & 0.61 & 0.77 & 0.62 & 1 & & & \\
\hline $\mathrm{SO}_{4}$ & 0.53 & 0.53 & 0.46 & 0.54 & 0.70 & 0.17 & 0.47 & 0.54 & 0.23 & 0.61 & 1 & & \\
\hline $\mathrm{PO}_{4}$ & 0.48 & 0.48 & 0.42 & 0.06 & -0.09 & 0.21 & 0.64 & 0.57 & 0.59 & 0.10 & -0.193 & 1 & \\
\hline $\mathrm{HCO}_{3}$ & 0.88 & 0.88 & 0.86 & 0.72 & 0.37 & 0.84 & 0.76 & 0.84 & 0.89 & 0.68 & 0.199 & 0.586 & 1 \\
\hline
\end{tabular}

Table 2. Correlation matrix for the water quality parameters 
Total hardness $(\mathrm{TH})$ also positively correlated with $\mathrm{Ca}, \mathrm{Mg}$ and $\mathrm{SO}_{4}$ which is logical since $\mathrm{TH}$ is a measurement of the first two elements and is approximately equal to their sum. The positive correlation between $\mathrm{TH}$ and $\mathrm{SO}_{4}$ can then be explained by reaction $\mathrm{E}_{3}$ and $\mathrm{E}_{4}$ (Li et al., 2013).

\section{Graphical Presentation of Data}

Most of the graphical methods are designed simultaneously to represent the total dissolved solids concentration and the relative proportion of certain major ionic species (Hem, 1989). Piper diagram are drawn by plotting the proportions (in equivalents) of major cations $\left(\mathrm{Ca}^{2+}, \mathrm{Mg}^{2+}, \mathrm{Na}^{+}+\mathrm{K}^{+)}\right.$on one triangular diagram (Piper, 1944). The proportion of major anions $\left(\mathrm{CO}_{3}^{-}, \mathrm{HCO}_{3}^{-}, \mathrm{Cl}^{-}\right.$and $\left.\mathrm{SO}_{4}{ }^{2-}\right)$ represents another triangular diagram. From the quadrilateral diagram the nature of cation and anion can be judged. Based on the observations, the major cation is $\mathrm{Na}+\mathrm{K}$ and anion is $\mathrm{Cl}^{-}$and $\mathrm{HCO}_{3}{ }^{-}$is found in all three seasons. The quadrilateral diagram shows that majority of water samples are of mixed $\mathrm{Ca}-\mathrm{Mg}-\mathrm{Cl}$ type which is presented in the Figure 2.

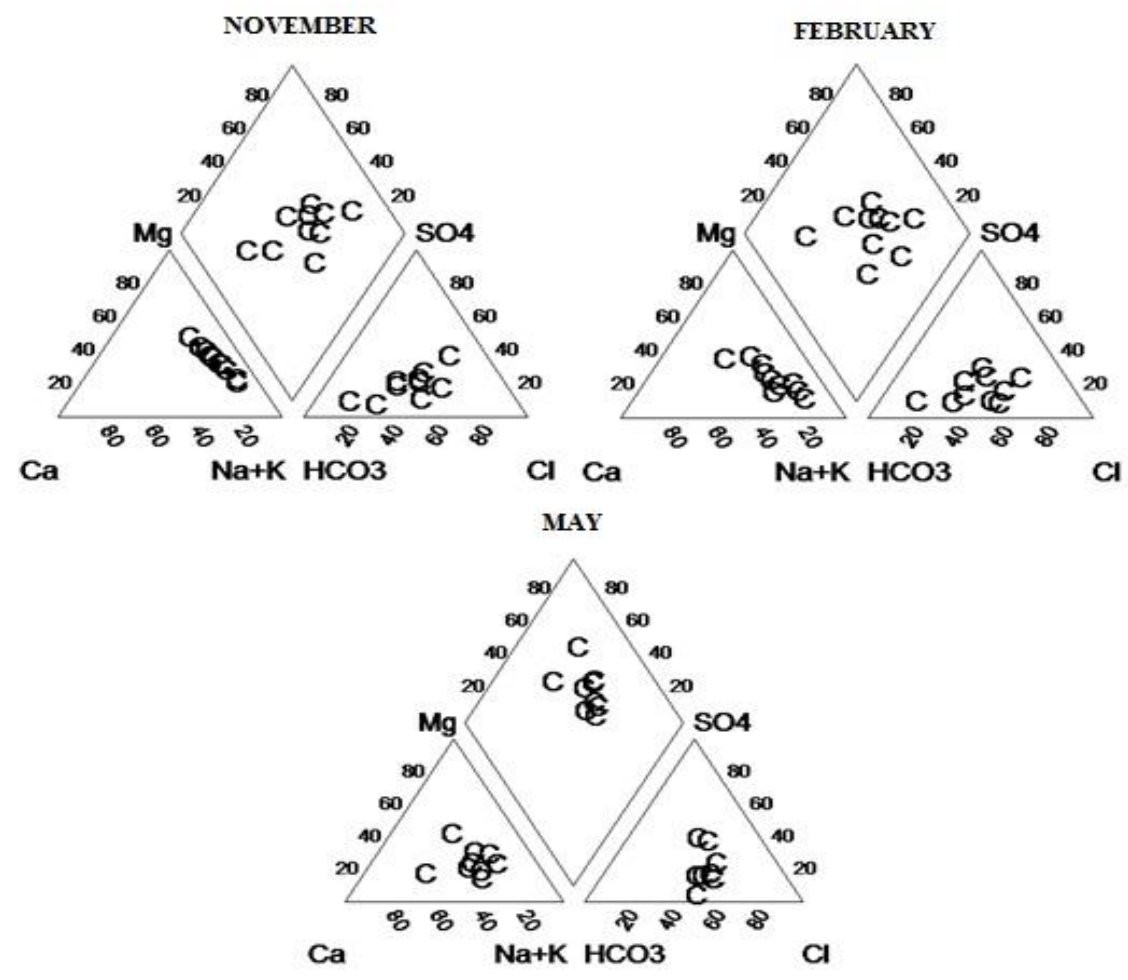

Figure 2. Piper trilinear diagram for groundwater samples

The Schoeller diagram represent the combination of major and minor constituents of groundwater in the study area in three seasons (Schoeller, 1967) which is presented in the Figure 3 and the result obtained indicates that $\mathrm{Na}, \mathrm{Cl}$ is dominant and $\mathrm{SO}_{4}$ is in low concentration. The orders of ions are $\mathrm{Na}, \mathrm{Cl}, \mathrm{Ca}+\mathrm{Mg}, \mathrm{HCO}_{3}$ and $\mathrm{SO}_{4}$. The box and whisker plot is a powerful statistical tool as it identifies the chemical parameters influencing the water chemistry in the study area. It demonstrates the median, range and shape of the data distribution (Figure 4). 

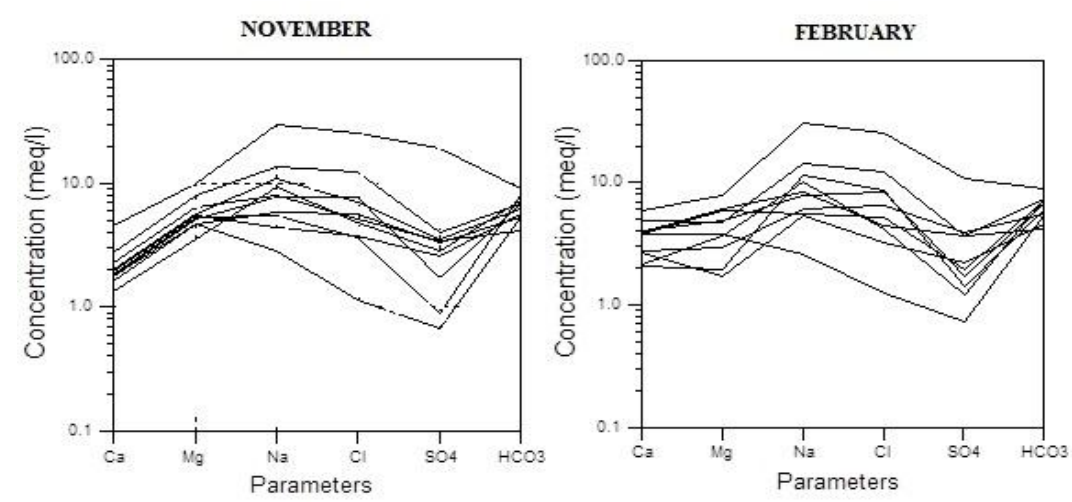

MAY

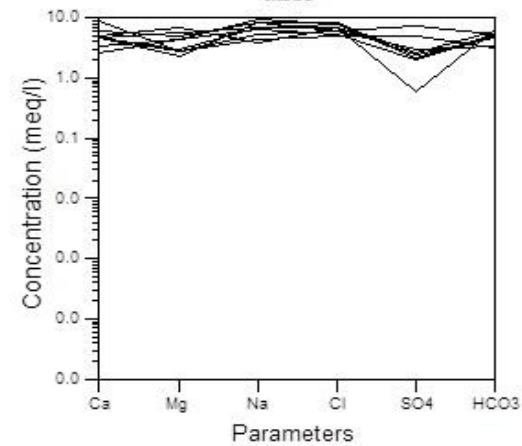

Figure 3. Schoeller diagram for groundwater samples
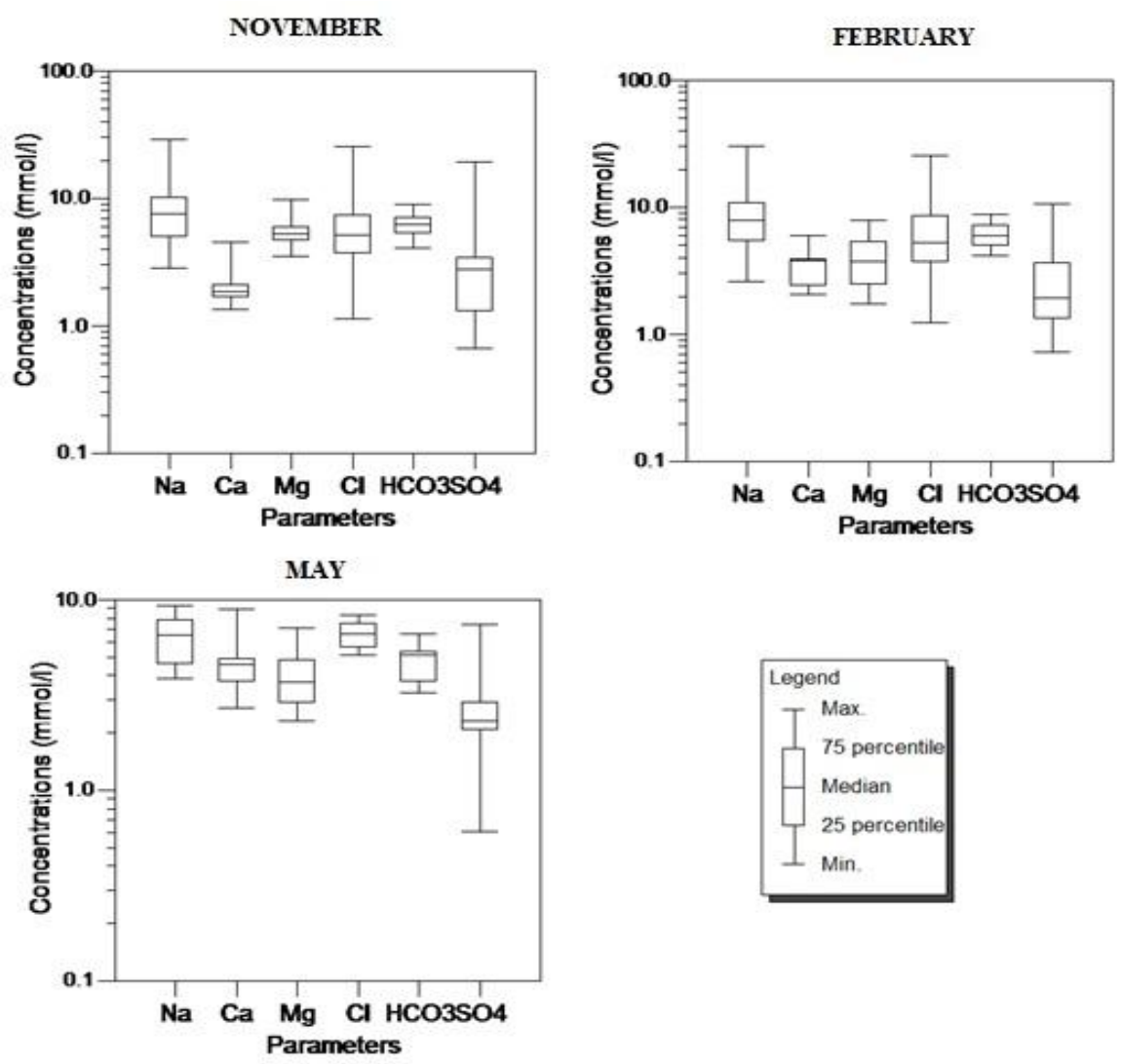

Figure 4. Box and whisker plot for groundwater samples

APPLIED ECOLOGY AND ENVIRONMENTAL RESEARCH 15(3):105-116. http://www.aloki.hu • ISSN 15891623 (Print) • ISSN 17850037 (Online) DOI: http://dx.doi.org/10.15666/aeer/1503_105116 (c) 2017, ALÖKI Kft., Budapest, Hungary 
The central box represents the values from the lower to upper quartile $\left(25^{\text {th }}\right.$ to $75^{\text {th }}$ percentile) and the vertical line extends from the minimum to the maximum values $\mathrm{A}$. (Tizro and Voudouris, 2008). The plot clearly shows $\mathrm{Na}^{+}, \mathrm{Ca}^{2+}, \mathrm{K}^{+}, \mathrm{Cl}^{-}, \mathrm{SO}_{4}{ }^{2-}$ and $\mathrm{HCO}_{3}{ }^{-}$ions that influence indication dominance of weathering and anthropogenic activities (Chidambaram et al., 2011). In all three seasons, $\mathrm{Na}, \mathrm{Ca}, \mathrm{Mg}$ is elevated and it may be due to cation exchange process. Durov diagram shows the type of water in the study area S.A. (Durov, 1948) which is showed in Figure 5. Durov diagram also shows that the dominant water type is $\mathrm{Na}+\mathrm{K}, \mathrm{Ca}+\mathrm{Mg}$ and mixed $\mathrm{Na}-\mathrm{Ca}-\mathrm{Mg}-\mathrm{Cl}$ type of water. In an anion region $\mathrm{Cl}^{-}$is most dominant type followed by $\mathrm{HCO}_{3}{ }^{-}$and $\mathrm{SO}_{4}{ }^{2-}$ type.
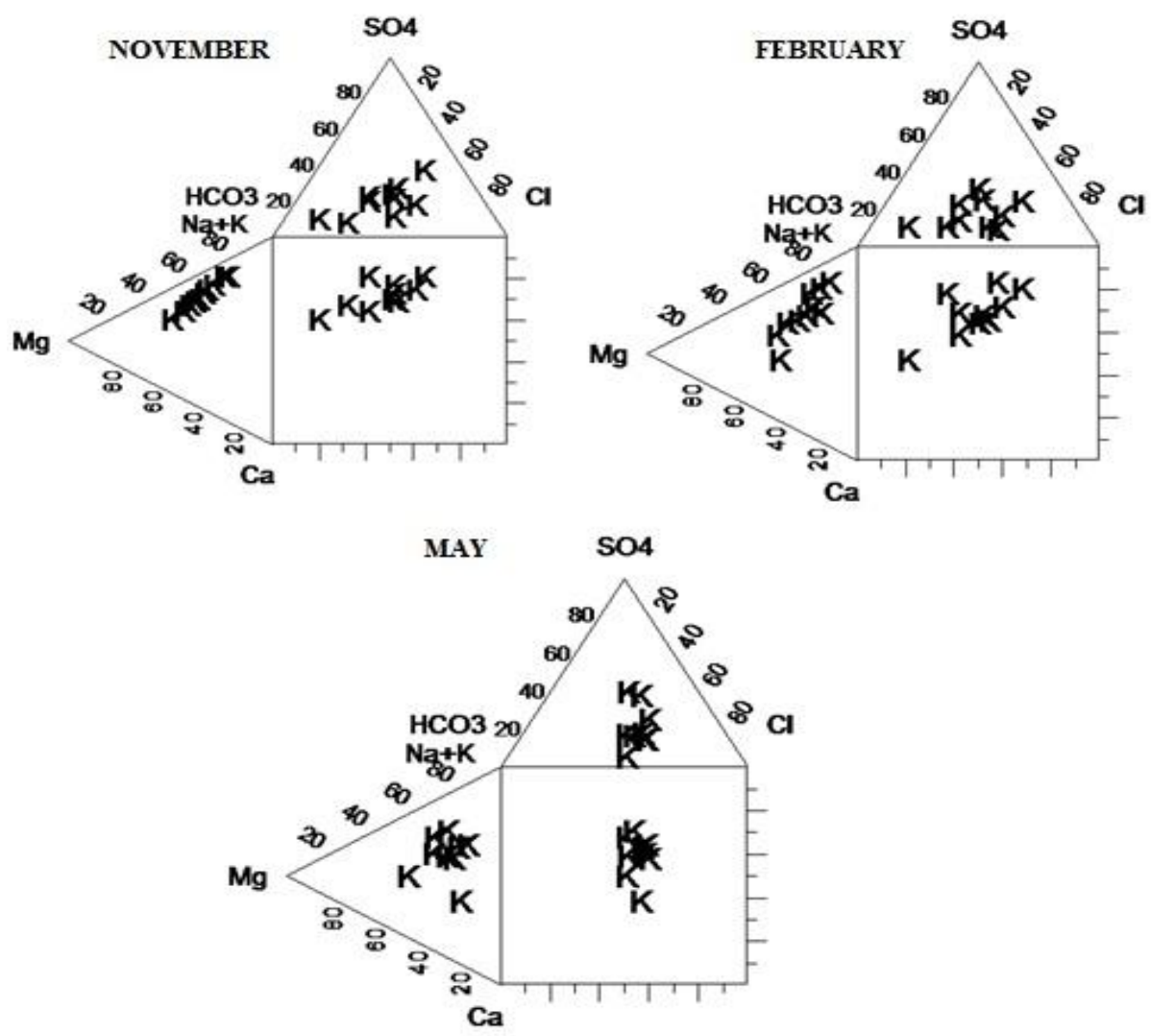

Figure 5. Durov diagram for groundwater samples

\section{Suitability of Industrial Purpose}

The water saturation index can be used to predict if water is precipitating out or dissolving or in equilibrium with calcium carbonate. A negative LSI value indicates the solution is under saturated with $\mathrm{CaCO}_{3}$. A positive value is supersaturated with $\mathrm{CaCO}_{3}$ and scaling may occur.

The Langelier saturation index (Degremont, 1991; Langelier, 1936) and the Ryznar saturation index (Ryznar, 1944) were determined to establish water suitability for industrial purpose. Langelier saturation index (LSI) can be calculated by taking difference saturation $\mathrm{pH}$ for $\mathrm{CaCO}_{3}$ using the following equation:

$$
\mathrm{LS} 1=\mathrm{pH}_{\mathrm{w}}-\mathrm{pH}_{\mathrm{s}}
$$


where $\mathrm{pH}_{\mathrm{s}}$ denotes the $\mathrm{pH}$ at saturation in calcium carbonate can be calculated using the equation (2):

$$
\mathrm{pH}_{\mathrm{s}}=(9.3+\mathrm{A}+\mathrm{B})-(\mathrm{C}+\mathrm{D})
$$

where constant $\mathrm{A}=(\log 10[\mathrm{TDS}]-1 / 10), \mathrm{B}=-13.12 \times \log _{10}\left({ }^{\circ} \mathrm{C}+273\right)+34.55, \mathrm{C}=\log 10$ $\left[\mathrm{Ca}^{2+}\right.$ as $\left.\mathrm{CaCO}_{3}\right]-0.4$ and $\mathrm{D}=\log _{10}\left[\right.$ Alkalinity as $\left.\mathrm{CaCO}_{3}\right]$.

A neutral LSI value indicates that the solution is at equilibrium with $\mathrm{CaCO}_{3}$ and it is neither scale forming nor a scale removing. The LSI values of groundwater in the study area of three seasons are presented in Figure 6. It clearly shows that almost all the station shows negative value; except one sample in the month of May. The neutral LSI value indicates the solution is in equilibrium with calcium carbonate (Singh et al., 2006) So there is no chance of scale formation.

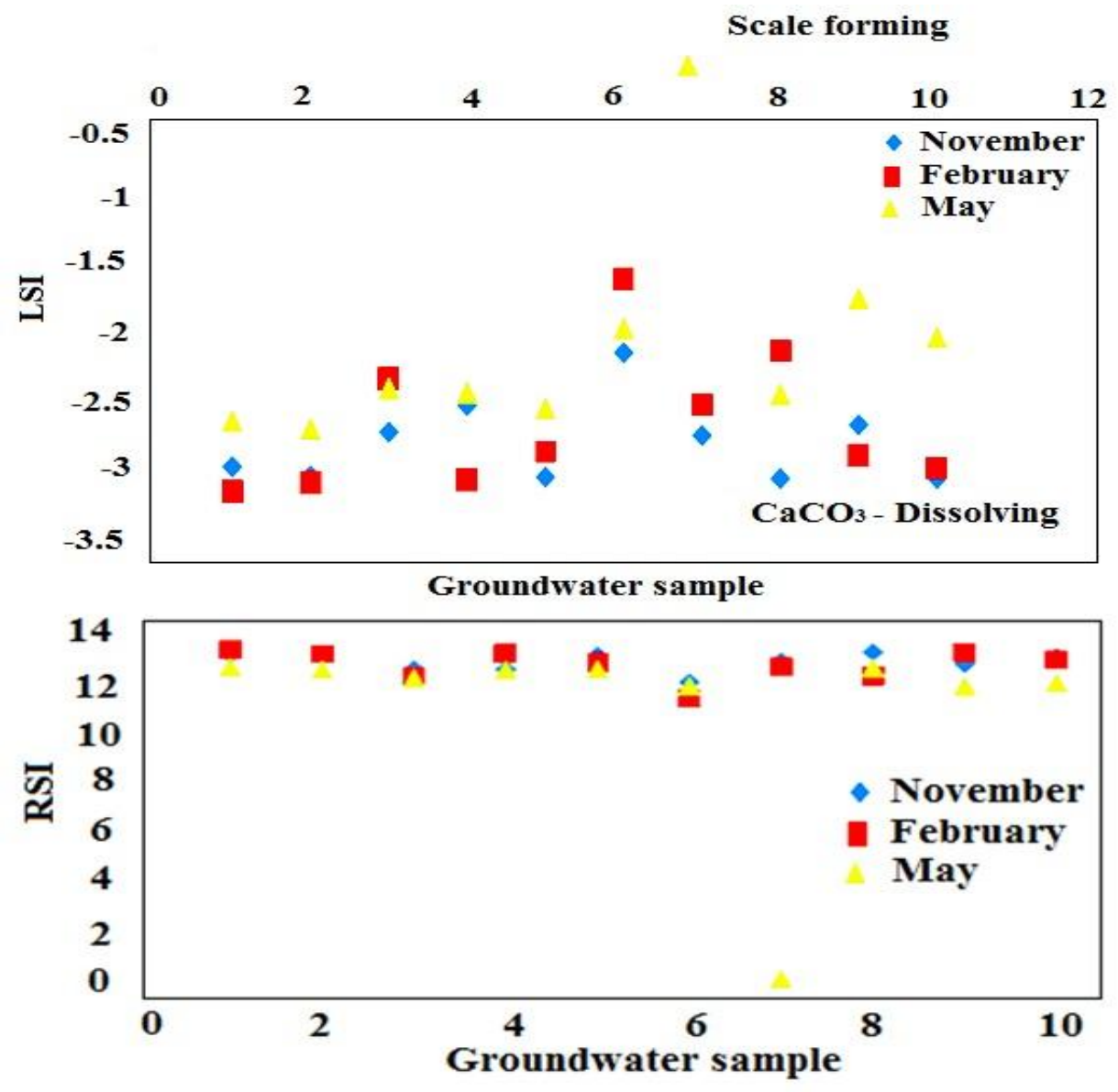

Figure 6. LSI and RSI of groundwater samples

John Ryznar changed the LSI in the year 1944. Like the LSI the Ryznar Saturation Index (RSI) is based on $\mathrm{CaCO}_{3}$ saturation in water except that the RSI gives only positive values. RSI values are calculated using the expression (3): 


$$
\mathrm{RSI}=2\left(\mathrm{pH}_{\mathrm{s}}\right)-\mathrm{pH}_{\mathrm{w}}
$$

where $\mathrm{pH}_{\mathrm{s}}$ is the saturation $\mathrm{pH}$ for calcium carbonate, $\mathrm{pH}_{\mathrm{w}}$ is the measured $\mathrm{pH}$ of water. Three seasons RSI values are presented in Figure 6, which indicates that similar results obtained like LSI (Table 3).

Table 3. RSI indicates the corrosion scale potential

\begin{tabular}{ll}
\hline RSI rating & Indication \\
\hline $4-5$ & Heavy Scale \\
$5-6$ & Light scale \\
$6-7$ & Very light scale \\
$>8$ & No scaling, corrosion \\
\hline
\end{tabular}

\section{Conclusion}

Water in Alathur block of Perambalur district shows slight alkaline to highly alkaline nature. All the graphical representation reveals that water is in mixed type of $\mathrm{Na}+\mathrm{K}$ and $\mathrm{Ca}-\mathrm{Mg}-\mathrm{Cl}$ type. The station $\mathrm{S} 7$ exceeds severely with respect to the permissible limits prescribed by BIS in two seasons. LSI and RSI of different samples clearly show that samples are $\mathrm{CaCO}_{3}$ dissolving type which indicates that there is no problem for industries. For drinking purposes some usual treatment has to be done before it is used. The alkaline nature of water yield of crop can be controlled by crop rotation policy.

\section{REFERENCES}

[1] Andrade, A.I.A.S.S., Stigter, T.Y. (2011): "Hydrogeochemical controls on shallow alluvial groundwater under agricultural land: Case study in Central Portugal. - Environ Earth Sci. 63: 809-825.

[2] APHA (2005). Standard methods for the examination of water and wastewater. 20th ed.American Public Health Association, Washington DC.

[3] BIS (1998). Drinking water specifications.- Bureau of Indian Standards, New Delhi.

[4] Chidambaram, S., Karmegam, U., Prasanna, M.V., Sasishar, P. and Vasanthavigar, M, (2011): A study of hydrochemical elucidation of coastal groundwater in and around Kalpakkam region, southern India. - Environ. Earth Sci. 64: 1419-1431.

[5] Cobbian, S.J., Nyame, F.K. and Obiri, S. (2012): Groundwater in the Sahelian region of Northern Ghana, West Africa. - Res. J. Environ. Earth Sci. 4: 482-2491.

[6] Degremont, G. (1991): Water treatment handbook (6th ed.) - Paris, France: Lavoisier Publishing.

[7] Durov, S.A. (1948): Natural waters and graphic representation of their composition. Akademiya Nauk SSSR Doklady 59: 87-90.

[8] Hem, J.D. (1989): Study and interpretation of the chemical characteristics of natural water (3rd ed.) - United States Geological Survey Water Supply Paper 2254.

[9] Jain, C.K., Bandyopadhyay, A., Bhadra, A. (2010): Assessment of groundwater quality for drinking purpose, District Nainital, Uttarakhand, India. - Environ. Monit. Assess. 166: 663-676.

[10] Joseph, K., Nagendran, R. (2004): Essentials of environmental studies. - Pearson Education, Singapore. pp. 10-23. 
[11] Langelier, W.F. (1936): The analytical control of anti-corrosion water treatment. - J. Amer. Water Work Assn. 28: 1500-1521.

[12] Li, P., Wu, J., Qian, H. (2013): Assessment of groundwater quality for irrigation purposes and identifications of hydrogeochemical evolution mechanisms in Pengyang country, China. - Environ. Earth Sci. 69: 2211-2225.

[13] Naidu, A.S., Mowatt, T.C., Somayajulu, B.L., Rao, K.S. (1985): Characteristics of clay minerals in the bed loads of major river of India. - SCOPE 58: 559-568.

[14] Piper, A.M. (1944): A graphical procedure in the geochemical interpretation of water, Trans. - Am. Geophys. Union 25: 914-928.

[15] Ramesh, K., Jagadeewari, P.B. (2012): Hydrochemical characteristics of groundwater for domestic and irrigation purposes in Periyakulam Taluk of Theni District, Tamilnadu. - I. Res. J. Environ. Sci. 1: 19-27.

[16] Ryznar, J.W. (1944): A new index for determining the amount of calcium carbonate scale formed by water. - J. Amer. Water Work Assn. 36: 472-494.

[17] Schoeller, H. (1967): Qualitative evaluation of groundwater resources. - In: Methods and techniques of groundwater investigation and development. Water Research Series-33: UNESCO, pp. 44-52.

[18] Shankar, B.A., Balasubramanya, N., Reddy, M.T.M. (2008): Impact of industrialization on groundwater quality - A case study of Peenya industrial area, Bangalore, India. Environ. Monit. Assess. 142: 263-268.

[19] Singh, M., Ansari, A.A., Muller. G., Singh, I.B. (1997): Heavy metals in the freshly deposited sediments of the Gomati river (a tributary of the Ganga River): effect of human activities. - Environ. Geo. 29: 246-252.

[20] Singh, K.P., Malik, A., Mohan, D., Singh, V.K, Sinha, S. (2006): Evaluation of groundwater quality in Northern Indo-Gangetic alluvium region. - Environ. Monit. Assess. 112: 211-230.

[21] Singh, A.K., Mahato, M.K., Neogi, B., Tewary, B.K., Sinha, A. (2012a): Environmental geochemistry and quality assessment of mine water of Jharia coalfield, India. - Environ. Earth Sci. 65: 49-65.

[22] Singh, V.K., Bikundia, D.S., Sarsat, A., Mohan, D. (2012b): Groundwater quality assessment in the village of Lutfullafur Nawada, Loni District Ghaziabad, Uttar Pradesh, India. Environ. Monit. Assess. 184: 4473-4488.

[23] Tank, D.K., Chandel, C.P.S. (2010): A hydrochemical elucidation of the groundwater composition under domestic and irrigated land in Jaipur City. - Environ. Monit. Assess. 166: 69-77.

[24] Tizro, A.T., Voudouris, K.S. (2008): Groundwater quality in the semi-arid region of the Chahardouly basin, West Iran. - Hydrolog. Process 22: 3066-3078.

[25] Vogel, A.I. (1968): A Text Book of Quantitative Inorganic Analysis Including Elementary Instrumental Analysis (3rd ed.) - ELBS/Longman, pp.121.

[26] Wang, Y., Jiao, J.J. (2012): Origin of groundwater salinity and hydrogeochemical processes in the confined Quaternary aquifer of the Pearl River Delta, China. - J. Hydol. 438-439: 112-124.

[27] Younger, P.I. (2007): Groundwater in the environment, an introduction. - Oxford: Blackwell Publishing.

[28] Zaporozec, A. (1972): Graphical interpretation of water quality data. - Groundwater 10: $32-43$. 